\title{
Tablas y figuras
}

\section{Tablas}

Tabla 2.1 Composición de la población latinx: grupos de origen nacional 16

Tabla 2.2 Composición racial de la población latinx 18

Tabla 2.3 Lengua dominante entre personas latinxs 35

Tabla 5.1 Clasificación racial en los censos de Estados Unidos 1790-2010 126

\section{Figuras}

Figura 2.1 Porcentaje de la población de cinco años o más edad que habla español en el hogar

Figura 2.2 Pregunta sobre la lengua de la Encuesta sobre la comunidad estadounidense (American Community Survey: ACS)

Figura 3.1 Mapa de 1765 que muestra las posesiones coloniales británicas y españolas en Norteamérica $\quad 45$

Figura 3.2 Línea cronológica de la conquista española y la anexión estadounidense 46

Figura 3.3 Misión de San Xavier en las afueras de Tucson (Arizona) 50

Figura 3.4 Mapa de la expansión territorial de Estados Unidos 52

Figura 3.5 Don't miss Plaza Hacienda $\quad 61$

Figura 3.6 Composición de la población latinx: grupos de origen nacional 67

Figura 3.7 La frontera entre México y Estados Unidos 70

Figura 4.1 Bienvenido a Estados Unidos: ¡Ahora HABLE INGLÉS! 86

Figura 4.2 Bienvenido a Estados Unidos: Ahora hable cheroqui 87

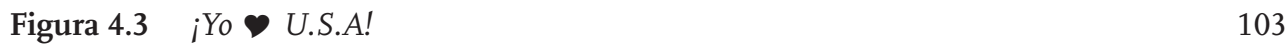

Figura 5.1 De Indio y Mestiza sale Coyote 130

Figura 5.2 Pregunta sobre origen hispano del censo de $2010 \quad 139$

Figura 5.3 Pregunta sobre raza del censo de $2010 \quad 141$ 
Tablas y figuras

Figura 5.4 Pregunta sobre la raza del censo de 2020

Figura 6.1 La bandera puertorriqueña junto a la estadounidense y una réplica de la Estatua de la Libertad en Reading (Pensilvania)

Figura 7.1 El paisaje lingüístico en el centro de Paterson (Nueva Jersey) 213

Figura 7.2 American Family Insurance 215

Figura 7.3 Ay! Mami “Una cocina caliente” 216

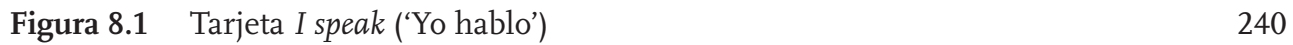

$\begin{array}{lll}\text { Figura 10.1 Tacos, plis! } & 292\end{array}$

Figura 10.2 Se nececita bosvoy y disguacher 293 